\begin{tabular}{c|cc|}
$\begin{array}{c}\text { ADVANCE RESEARCH JOURNAL OF SOCIAL SCIENCE } \\
\text { RESEARCH } \\
\text { ARTICLE }\end{array}$ & $\begin{array}{c}\text { Volume 6 | Issue 2 | December, 2015 | 173-180 } \\
\text { e ISSN-2231-6418 }\end{array}$ \\
\hline DOI: 10.15740/HAS/ARJSS/6.2/173-180 & Visit us : www.researchjournal.co.in
\end{tabular}

\title{
A study of emotional intelligence and frustration tolerance among adolescent
}

Archana Kumari* and Sandhya Gupta

The IIS University, JAIPUR (RAJASTHAN) INDIA

(Email: Archana.kumari@ iisuniv.ac.in; Sandhyagupta594@gmail.com)

\section{ARTICLE INFO :}

$\begin{array}{lll}\text { Received } & : & 14.07 .2015 \\ \text { Revised } & : & 22.10 .2015 \\ \text { Accepted } & : & 03.11 .2015\end{array}$

KEY WORDS :

Emotional intelligence, Frustration, Tolerance, Adolescent

\section{HOW TO CITE THIS ARTICLE :}

Kumari, Archana and Gupta, Sandhya (2015). A study of emotional intelligence and frustration tolerance among adolescent. Adv. Res. J. Soc. Sci., 6 (2) : 173-180.

*Author for correspondence

\section{ABSTRACT}

In every sphere of life whether it is education, academic or personal, adolescents feel lots of obstacles on the way of their goals in life. Sometimes they are able to deal with them rationally but sometimes they deal with it emotionally. In case if they are incapable to deal with these obstacles they get frustrated. To cope up with frustration the adolescents need to be emotionally intelligent that means they should have flexibility, optimist thought and skilled to control impulses. The present study attempted to correlate frustration tolerance with emotional intelligence. A total of 120 adolescents were selected from Jaipur city in the age group of 12-19 years of age. Out of 120 adolescents, 60 were girls and 60 were boys. For data collection Emotional intelligence scale and Frustration tolerance tool was used. A positive correlation was found between emotional intelligence and frustration tolerance of adolescents. Girls were found to have high emotional intelligence as well as frustration tolerance as compared to boys. A significant difference was found in emotional intelligence and frustration tolerance at different age. Adolescents of 12-15 years have high emotional intelligence and frustration tolerance than adolescents of 16-19 years. 